\title{
Sustainability transformations: a resilience perspective
}

\author{
Per Olsson $^{1}$, Victor Galaz ${ }^{1}$ and Wiebren J. Boonstra ${ }^{1}$
}

\begin{abstract}
Scholars and policy makers are becoming increasingly interested in the processes that lead to transformations toward sustainability. We explored how resilience thinking, and a stronger focus on social-ecological systems, can contribute to existing studies of sustainability transformations. First, we responded to two major points of critique: the claim that resilience theory is not useful for addressing sustainability transformations, and that the role of "power" in transformation processes has been underplayed by resilience scholars. Second, we highlighted promising work that combines insights from different theoretical strands, a strategy that strengthens our understanding of sustainability transformations. We elaborated three research areas on which such combined perspectives could focus: innovation and social-ecological-technological systems interactions, patterns of transformation, and agency and transformation.
\end{abstract}

Key Words: agency; innovation; resilience; social-ecological systems; sustainability transformation

\section{INTRODUCTION}

Scientists concerned about the future of the planet have for more than a decade pointed to the urgent need for sustainability transformations (Clark 2001, Kates et al. 2001, Raskin et al. 2002, Schellnhuber et al. 2011, Weinstein et al. 2013). They recognize that such shifts require radical, systemic shifts in values and beliefs, patterns of social behavior, and multilevel governance and management regimes. For example, the first Nobel laureate event and the Potsdam Memorandum pondered the Great Transformation and pleaded for fundamental changes in our economies and societies to achieve sustainability. In the proceedings from the meeting, Gell-Mann (2010) identified a set of interlinked transitions that must occur if the world is to shift from present trends to greater sustainability: (1) a demographic transition, (2) a technological transition, (3) an economic transition, (4) a social transition, (5) an institutional transition, (6) an informational transition, and (7) an ideological transition. Despite these pleas for major change, there is still a need to increase the understanding of the mechanisms and patterns, as well as conditions, underlying transformations. This would greatly increase the chances for successfully navigating transformations and embarking on sustainable trajectories.

A number of promising conceptual frameworks have emerged for studying sustainability transformations, including transition management and resilience theory. Both of these describe sustainability transformations as multilevel, multiphase, and cross-scale processes but have different points of departure and theoretical focuses. The main difference is that resilience scholars have focused mainly on the capacity of social-ecological systems to deal with disruptive change, whereas transition management scholars have focused on achieving nonlinear change in sociotechnological systems. However, over the past decade, these fields have moved closer together; the resilience field is now looking at issues traditionally addressed by transition management scholars, such as technological change, transformation, governance, and social aspects. Likewise, the field of transition management reflects an interest in themes familiar to resilience scholars: socialecological systems, biodiversity, and ecosystem services.

Resilience theory has a strong focus on social-ecological system dynamics and interactions. It builds on the notion that humans are ultimately dependent on healthy ecosystems for their wellbeing and that paying attention to ecosystems' capacity to generate essential services is of crucial importance (Berkes and Folke 1998). Folke et al. (2011) argue that any attempts to create sustainability transformations should involve strategies for "reconnecting to the biosphere," which entails a view of humans and nature as an integral whole within which a healthy planet is the premise for economic and social development. Resilience scholars also pay attention to the mismatches between environmental governance systems and ecosystem dynamics, which threaten to erode social-ecological resilience and push lifesupporting ecosystems over critical thresholds into more degraded, less productive regimes. For our purpose, we define sustainability transformations as shifts that fundamentally alter human and environmental interactions and feedbacks (Walker et al. 2004).

Since the mid-1990s, a growing group of resilience scholars have been studying transformations toward improved ecosystem stewardship and global sustainability (e.g., Gunderson et al. 1995, Gunderson and Holling 2002, Olsson et al. 2004b, 2006, Walker et al. 2004, Chapin et al. 2010, Folke et al. 2010, Westley et al. 2011). Their work explores the interrelations between agency, networks, institutions, and innovation. A main focus has been on the emergence of new governance and management systems that can restore, sustain, and develop the capacity of ecosystems to generate essential services. Most of these studies have been carried out at local to national levels. However, in light of the recent work in Earth system science and on planetary boundaries (Rockström et al. 2009, Walker et al. 2009, Steffen et al. 2011), Westley et al. (2011) also discuss the need for radical transformations in humanenvironmental interactions and feedbacks to reverse current trends of crossing critical thresholds and tipping points in the Earth system.

Despite extensive work on transformations, resilience theory has been criticized for lacking the analytical power to study such shifts, especially regarding social aspects (see, e.g., Jerneck and Olsson 2008, Pelling and Manuel-Navarrete 2011). Some of the criticism is relevant for improving theory development, but some of it builds on a misunderstanding of the theory. We aim to respond to issues raised in the debate and to help clarify some 
misinterpretations. We start by discussing and responding to the specific critique raised against resilience-based theories on transformation. Finally, we show how the fields of transition management and resilience can be integrated and how this combination could strengthen our analytical capacities for understanding sustainability transformations.

\section{RESPONSE TO COMMON CRITICISM}

We summarize the main points of critique raised against resilience thinking, mainly drawn from Smith and Sterling (2010), Voß and Bornemann (2011), Jerneck and Olsson (2008), and Pelling and Manuel-Navarrete (2011), but also from other relevant literature. There are two major points of critique: the first one questions whether resilience theory is useful for addressing sustainability transformations, and the second one concerns power issues related to these transformations. We aim to clarify some misunderstandings, respond to the critique, and identify central questions for future research.

\section{Addressing sustainability transformations}

Some critics argue that resilience theory is biased toward persistence and is less suited for the analysis of transformations (see, e.g., Jerneck and Olsson 2008, Pelling and Manuel-Navarrete 2011). Smith and Sterling (2010) join this critique when they raise the question of whether structures or functions of socialecological systems are, or should be, resilient. They point out that when social/political domains are included in the analysis, maintaining functions does not necessarily correspond to maintaining structures. For example, resilient socio-political structures can have a negative effect on ecosystem functions, which in turn can reduce the resilience of ecosystems and their ability to produce services (see also Jerneck and Olsson [2008] for a similar critique). Holling et al. (2002) coined the concept of the rigidity trap for this type of maladaptation. It occurs when a system's resilience is high, i.e., when it has great ability to resist external disturbance and persist, "beyond the point where it is adaptive and creative" (Holling et al. 2002:96). In rigidity traps, a high degree of connectivity and the suppression of innovation prolong an increasingly rigid state, which can result in an undesired regime shift in the system.

The early form of resilience theory could be criticized for being vague on the relationship between the resilience of social and political systems and the resilience of the social-ecological system of which these subsystems are part. We agree that the resilience literature often treats resilience as something good. More recently, however, resilience scholars have been much more explicit about the type of resilience and the systems, or domains, to which it applies. Marschke and Berkes (2006) address the notion of bad resilience using the concept of traps, which means that selfreinforcing social and ecological feedback can create lock-ins that make moving to alternate regimes and into new trajectories extremely difficult. The tendency to lock into such patterns comes at the cost of the capacity to respond to new problems and opportunities. For example, archaeological studies show that people of the Hohokam region, in the Southwest of the United States, developed a culture and a way of life that offered few alternatives, which led to a societal collapse (Hegmon et al. 2008). Although conditions worsened, households failed to relocate despite generations of poor health conditions, until the social and physical infrastructure ultimately fell apart.
Resilience scholars are working to understand social-ecological traps (Steneck et al. 2011, Boonstra and de Boer 2014), both how they are created and how to escape them. For example, Enfors (2013) maps the drivers and feedback loops that keep small-scale agricultural social-ecological systems in dryland sub-Saharan Africa in a poverty trap. This mapping helps to clarify when, where, and how small-scale farm innovations can break reinforcing feedback loops that keep the social-ecological system on an undesirable trajectory, to enable communities to escape poverty traps, shift livelihoods, and secure long-term provisioning of ecosystem services (Enfors 2013). In a similar way, Sendzimir et al. (2008) map the structure of two competing sets of feedback loops in a water management regime in the Tiscza River, Hungary, where the dominating loop keeps the system in an undesired regime and on an unsustainable trajectory.

These studies focus on the interactions between the social and ecological subsystems, how certain social structures and functions affect ecosystem structures and functions, and how this either enhances or reduces the resilience of the interconnected socialecological system. These studies clearly illustrate the need to specify the system or subsystems of interest as a way to address incorrect assumptions that managing for resilience aims to maintain or enhance resilience for its own sake (Leach et al. 2007, Voß and Bornemann 2011).

The same misunderstanding, i.e., believing that resilience scholars always assume that resilience is something good, leads Smith and Sterling (2010) to argue that there is a need to restrict the term resilience to the ability to maintain system structure and function in the face of shocks, whereas the term robustness can refer to the ability to maintain system structure and function for transformation in the face of long-term stresses. In conclusion, Smith and Sterling, as well as others (Pelling and ManuelNavarrete 2011), rightfully argue that robustness and resilience might be two distinct and different qualities. However, we argue that resilience thinking and research address them both, and that these authors have not considered the conceptual refinements and redefinitions that have been introduced to clarify precisely the confusion that they highlight (see Anderies et al. [2013] for an overview of the work in this area). Two of these concepts, i.e., adaptability and transformability, stand out because they make a distinction between different aspects of resilience (Walker et al. 2004, Folke et al. 2010). Transformability refers to the socialecological capacities that enable shifts from one regime to another, and adaptability refers to the capacities to deal with change and stay within a regime.

Using this distinction leads us to agree with the critics who argue that the value of the concept of adaptive management is limited for understanding and analyzing sustainability transformations. Adaptive management (Holling 1978), together with its sister concept adaptive comanagement (Olsson et al. 2004a, Armitage et al. 2007), is linked to adaptability and is adequate for analyzing how to maintain a certain regime and stay on the same trajectory in the face of uncertainty and change. These concepts help explain adaptability but are insufficient for understanding transformability, which calls for different analytical approaches. To give an example, the adaptive comanagement framework is useful for analyzing the social-ecological capacities for managing the Kristianstads Vattenrike Biosphere Area in the face of 
uncertainty and change, remaining on the same trajectory (Olsson et al. 2007), but is inadequate for understanding the socialecological capacities for establishing the biosphere area and the sequence of events that led to the new governance mode, overcoming path dependence, and transforming into a different trajectory with changed human-environmental interactions and feedbacks. A pioneering study in this regard is by Marshall et al. (2012) who investigated the difference between adaptive and transformative capacity among peanut farmers in Queensland, Australia. They show how features such as place attachment and occupational identity are positive for adaptability but negative for transformability, particularly involving relocation or loss of place.

In summary, we think that the critique that resilience is not adequate for addressing transformations builds on a misconception of the theory. Resilience scholars do make a distinction between adaptation and transformation, and the mechanisms that reinforce a certain trajectory as well as support shifts from one trajectory to another (Walker et al. 2004, Folke et al. 2010). This distinction in the analysis of sustainability transformations is also starting to be applied in other academic fields, such as human geography (O'Brien 2012).

The cross-scale interactions are crucial in this regard, especially for understanding the interplay between these concepts across scale. Folke et al. (2010) explain this in the following way:

Multi-scale resilience is fundamental for understanding
the interplay between persistence and change,
adaptability and transformability. Without the scale
dimension, resilience and transformation may seem to be
in stark contrast or even conflict. Confusion arises when
resilience is interpreted as backward looking, assumed to
prevent novelty, innovation and transitions to new
development pathways. This interpretation seems to be
more about robustness to change and not about resilience
for transformation.

This points to the fact that, as in any complex adaptive system, adaptation at one scale might require transformations at other scales, and building resilience at a certain scale can reduce resilience at other scales. These dynamics are a central part of the panarchy theory (Gunderson and Holling 2002) and have sparked a number of empirical studies of social-ecological systems at a wide range of scales and dimensions, from rangelands (Marshall and Stafford Smith 2010), shallow lakes (Peterson et al. 2003), and river systems (Schlüter and Herrfahrdt-Pähle 2011) to coral reefs (Olsson et al. 2008), and from fisher communities (Cinner et al. 2012) to global markets (Österblom and Sumaila 2011); they have also been used to analyze the interaction between these different scales and dimensions (Cash et al. 2006, Folke et al. 2011, Kok and Veldkamp 2011, van Apeldoorn et al. 2011, Galaz et al. 2012b). For example, Reij and Smaling (2008) investigate how the diffusion of small-scale farming innovations affects large-scale impacts on regreening Africa's drylands and the Sahel in particular. Hence, we recognize that transformations at one scale do not take place in a vacuum but in a cross-scale context where, for example, novelty and innovation are drawn from other scales or other systems at specific times.

Resilience scholars have also explored the role of agency in navigating social-ecological system transformations and in linking processes across scales (Olsson et al. 2004b, 2006, Chapin et al. 2010, Brown and Westaway 2011, Westley et al. 2011, 2013). The literature tends to define such agency as involving individuals, organizations, and/or networks, using concepts such as "institutional entrepreneurship," "transformational leadership," and "shadow networks." Three main phases of transformations in social-ecological systems have been identified: (1) preparing for transformation, (2) navigating the transition, and (3) building the resilience of the new direction (Olsson et al. 2004b). The first and second phases tend to be linked by a window of opportunity. In the preparation phase, agents of change and their networks may work simultaneously at different scales of the social-ecological system. By intervening at broader institutional levels, they can open up new trajectories of development. In the navigation phase, cross-scale brokers can provide bridging functions that connect different actors operating at different scales and launch new initiatives and scale up innovations (Rosen and Olsson 2013). In the building resilience phase, bridging organizations can create incentives and foster values for stewardship in the new context.

These studies build on the notion that complex adaptive systems are characterized by uncertainty and surprise. This means that the effects of human actions can never be fully anticipated or predicted (Portes 2000) and will have unexpected and unintended consequences. For this reason, many resilience scholars focusing on transformations use words such as emerging and navigating over managing, steering, or controlling transitions. The former concepts relate closely to alternative options described in the literature, such as piecemeal engineering (Popper 1960 [1957], 1962 [1945]), pronesis (Flyvbjerg 2001), metis (Scott 1998), or learning by doing (Berkes et al. 2003). Some of these might be well-planned management practices; others are better described as muddling through (Lindblom 1959, 1979) or improvisation (Tilly 1999).

\section{Addressing power issues}

One of the most frequently raised objections is the neglect of the working of power in resilience studies. In its less constructive form, resilience theory is criticized for stabilizing and reinforcing "an incumbent (capitalist) political economy" (Voß and Bornemann 2011:2-3, see in particular Nadasdy 2007, Hornborg 2009). A more useful critique raises concerns that by not accounting for power dynamics, managing for resilience runs the risk of reproducing inequality and domination. It is therefore suggested that resilience theory needs to address the wider political contexts in which social-ecological change is embedded. Voß and Bornemann (2011:15) find resilience thinking "depoliticized" and showing a "disregard for nasty politics." In a similar way, Smith and Sterling (2010:8-10) outline "critical challenges" for resilience theory, which all have to do with questions of "power."

Studies of power are commonly used to assign responsibility or blame to individuals or groups. They refer to a "moral context" (Morriss 2002:38) and often conceptualize power as power over: "when A affects B in a manner contrary to B's interests" (Lukes 1974:37). Young (2006:118) labeled this approach "the liability model," in which there must be "clear rules of evidence, not only for demonstrating the causal connection between a given agent and a given harm, but also for evaluating the intentions, motives, and consequences of the actions." 
In some cases, the impacts of how the abuse of power can contribute to loss of resilience can be easily identified, e.g., subsidies that support overfishing, corrupt governments that contribute to deforestation, and so forth; in other cases, complex interactions in social-ecological systems make this a highly difficult task. Power often refers to structural injustice, which is typically "a result of human action, but not of human design" (Ferguson 1995 [1767]:122). For these types of situations, several scholars have argued that it is more helpful to think in terms of "power to" Morriss (2002:34) and "social connections" (Young 2006). Power to refers to "the ability to effect outcomes" (Morriss 2002:36), which can be severely impaired because of forms of structural injustice (Young 2006).

Although the definitions and approaches for studying power differ considerably in the literature, we agree that power issues have been understudied by resilience scholars and need to be addressed in the future (Brown 2014). This, however, requires a clear definition of the type of power relations being addressed (e.g., "power to" or "power over") and their relationship to the dynamics of socialecological change.

Nevertheless, the critique does not specify how power and resilience can be addressed in relation to the concepts of adaptability or transformability. By definition, adaptability helps to reproduce social-ecological systems, whereas transformability helps to transform them. This leads to confusion about how resilience scholars actually can address power and the research gaps that need to be filled. For example, resilience scholars have addressed power as part of adaptability to a greater extent than as part of transformability. The former includes studies of power as part of "good governance" of social-ecological systems (Lebel et al. 2006). Concepts such as comanagement, adaptive comanagement, or adaptive governance explore closely related issues such as power sharing, decentralization and devolution of management rights, power asymmetries, and injustices that arise from structural inequalities of power (see, e.g., Adger et al. 2005, Galaz 2005, Cowling et al. 2008, Ernstson et al. 2008, Crona and Bodin 2010, Moore and Tjornbo 2012). This literature addresses both issues of "power over" and "power to" and emphasizes that the redistribution and sharing of power is one of the key conditions for more flexible, collaborative forms of management and governance that contribute to long-term resilience of socialecological systems.

The challenge for resilience scholars is to address power as part of transformability. It is true that few studies of transformation in social-ecological systems have power as a central focus of their analysis. Instead, it has been treated as one of several equally important variables that constitute a regime (Olsson et al. 2010). Gelcich et al. (2010) shows the emergence and the empowerment of a shadow network that could leverage locally coproduced knowledge into national negotiations regarding new fishery policy after the political shift. They describe how a new governance approach for marine resources emerged in Chile at a time of marine resource crisis and political turbulence. The resource crisis in the 1980s triggered a few collaboration initiatives between fishers and scientists who, for different reasons, started to experiment with new approaches and solved their problems together. Political turbulence in the late 1980s provided a window of opportunity for fishermen to organize, transfer the knowledge from these experiments, and influence the new national fishery legislation in the 1990s. Similarly, Österblom and Folke (2013) show the connections between agency and institutional change in the shift from open access and illegal fishing to an adaptive governance system in the Southern Ocean. These processes typically include overcoming path dependence and self-reinforcing feedbacks and moving across thresholds and tipping points to create the conditions for more flexible, collaborative forms of governance and management of natural resources and ecosystem services.

Overcoming reinforcing feedback requires reconfiguring power relationships (Motion 2005) that contribute to the status quo and bad resilience combined with strategies and transformational agency. Reconfiguring power also requires paying attention to scale (Sneddon 2003, Cash et al. 2006) and, more specifically, to how biophysical and social scales are linked (Veervoort et al. 2012). Peterson (2000), for example, uses a resilience approach to map political power across scales, which can help to identify opportunities for change. Another helpful starting point toward the study of power relations in transformation processes in socialecological systems involves the questions raised by O'Brien (2012): Who decides to initiate transformations? Can transformations be carried out in a deliberative, participatory manner that is both ethical and sustainable? How can power, politics, and interests present barriers, or pathways, to transformation?

\section{INTEGRATING RESEARCH FIELDS}

There are several research fields that address sustainability transformations and that can help deal with the issues and questions raised in the previous sections. These include social innovation, social movement, social-ecological systems' resilience, and socio-technological transitions. We focus on the two latter ones and discuss how these can be integrated and how this combination could strengthen our analytical capacities for studying sustainability transformations. We start by identifying some of the most apparent similarities and differences.

From the start, theories of socio-technological transitions have acknowledged the need to account for ecological change in their models and analyses (Grin et al. 2010). However, they treat ecological aspects as background variables, at the landscape scale, driving sustainability transformations, or as part of a vision of future desirable systems. However, ecological aspects are not part of the system assessment. For instance, ecosystem shocks are not acknowledged as disruptive drivers, nor are visions positioned against a broader ecosystem view. Further, these theories do not address the possible impact of desirable future systems on biodiversity and ecosystem services. This is important because many socio-technological systems such as housing, water management, energy, and food production are intrinsically connected to and affected by ecosystem dynamics.

In contrast, the primary focus for resilience thinking (sensu Holling) is on complex social-ecological systems. It emphasizes that a focus on connectedness between nature and human society is particularly important for understanding sustainability transformations that are needed for humanity to stay within planetary safe operating space (Folke et al. 2011, Westley et al. 2011). The argument is that societies may undergo major social and technological transformations without improving their capacity to learn from, respond to, and manage environmental 
feedback from dynamic ecosystems (Olsson and Galaz 2012). However, one of the shortcomings of resilience research is in the lack of focus on the role of technology in sustainability transformations (Galaz 2012, 2014).

An understanding of interconnected social, technological, and ecological systems is crucial to prevent undesirable and unintended outcomes of initiatives to move toward sustainability. For example, there is currently an ongoing adoption of biofuels as a substitute for oil globally, and although a systemic shift to biofuels might slow down climate change, it also leads to destructive land-use change and biodiversity loss when scaled up on a global level (Grau and Aide 2008). This, in turn, can induce further ecological degradation, regime shifts, and structurally persistent social-ecological states that are difficult to get out of. It has also led to land being used to cultivate fuels instead of food and governments buying up land in countries, mostly in the Global South, to secure their own energy supply, which in turn has led to increased inequalities and conflicts (Borras and Franco 2010). This example illustrates how well-intended attempts to advance sustainability transformations can have adverse social and ecological consequences when implemented on a large scale unless the social, technological, and ecological aspects of systems, and their interactions, are addressed simultaneously. An integration of the social-ecological and socio-technological systems' perspectives could help in addressing humanenvironmental interactions more broadly. Hence, further analysis would therefore benefit from a closer collaboration and crosspollination between the fields of resilience and transition management.

Transition management scholars have developed an elaborate and detailed model for understanding cross-scale interactions in socio-technological systems, which entails niches at a microscale, regimes at a mesoscale, and landscapes at a macroscale (see, e.g., Rotmans et al. 2001, Geels and Schot 2007, Loorbach and Rotmans 2010). They define regimes as dominant rule sets, social networks and organizations, and prevailing infrastructures. Landscapes are defined as the geographic position of the land, climate, available resources, political constellations, economic cycles, and broad societal trends. Niches are defined as small, protected spaces in which new practices can develop, protected from harsh selection criteria and resistance from prevailing regimes. Their research focuses on the dynamics within each scale as well as cross-scale interactions, for example, the mechanisms by which niches can cause change at the regime and landscape scales.

Although less sophisticated in addressing the social aspects of these cross-scale dynamics, the panarchy theory has a similar focus. In the context of the niche causing change at the regime and landscape levels discussed previously, panarchy theory puts a stronger emphasis on the thresholds and tipping points involved in such shifts. It also has a specific focus on how the socialecological interactions and feedbacks change in these processes. Another important difference is that this theory deals more specifically with the role of crisis or disturbances in triggering and driving transformations.

The current debate among resilience scholars centers on what constitutes a regime shift and whether all regime shifts are transformations (Walker and Salt 2012). The question is how to distinguish between a regime shift within the same system, i.e., a change in the stability domain, and a change to a different system with different feedbacks and a different set of defining state variables. Although there is no clear answer to this question, a promising initiative that will help explore this is the Regime Shift Database (http://www.regimeshifts.org). This initiative compiles examples of various types of regime shifts that have been documented in ecosystems and social-ecological systems. The database focuses particularly on regime shifts that have major impacts on ecosystem services, and therefore on human wellbeing. Many of the initial entries into the database have focused on unintended shifts to more degraded ecological and socialecological systems. The next step for this initiative is to start entering cases of actively navigated social-ecological transformations (as defined by Olsson et al. 2006, Chapin et al. 2010).

Synthesizing, analyzing, and comparing social-ecological transformations will be an opportunity to connect resilience scholars to other fields that focus on transformations, including transition management and human geography. For example, resilience research would benefit greatly from the insights on the role of power in innovation and transition management (Avelino 2009, Avelino and Rotmans 2009, 2011) to analyze both the structural power of regimes to sustain their position as well as innovative power to transform regimes.

Panarchy theory emphasizes that building transformative capacity requires systemic experimentation and innovation and ways to coordinate and combine these across scales at critical times. This is also in line with the findings of scholars in transition management (e.g., Grin et al. 2010, Loorbach 2010) who argue that the ability to create space for and coordinate collaborative experiments that contribute to system innovation is of crucial importance in releasing lock-ins and enabling shifts to new trajectories. They highlight, for example, the role of transition arenas and their importance in experimenting with new approaches for governing water resources in the Netherlands (van der Brugge and van Raak 2007). These arenas are particularly useful for exploring value conflicts, contradicting worldviews, and solving tensions among stakeholders. From a resilience perspective, such "systemic experiments" should focus on broadening the diversity of options, ideas, institutions, organizational settings, and practices (see, e.g., Bormann and Kiester 2004, Rudd 2004) in relation to social-ecological systems and ecosystem services (Cummings et al. 2013). A combination of resilience and transition management perspectives could help design studies of interactive innovation spaces or change labs (Westley et al. 2011) and the role they play for experimenting with new configurations of linked social and ecological systems and enabling the emergence of different sets of feedbacks.

Integrating these research fields will be, of course, far from easy, especially because the different fields embed different hidden values, ask different questions, employ different methods, and gather and analyze different data (cf. Lélé and Norgaard 2005, Miller et al. 2008, Strang 2009). In addition, there is a difficult balance between theoretical simplicity and elegance, and frameworks with the ambition to provide understandings of complex processes. This however, should not be seen as an impossible obstacle as we aim to move beyond disciplinary 
boundaries and create a better understanding of transformations in linked social, ecological, and technological systems. There are clear points for collaboration and integration, and some tangible attempts have been made to elaborate the intersection between socio-political, ecological, and technological systems. Subsequently, we will briefly consider some of these attempts.

In their study of transitions in water governance, the NeWater project, Pahl-Wostl et al. (2005, 2007) propose an integrated transition framework, including social-ecological dynamics, network features, and institutional factors. Similar to the research on resilience and social-ecological systems, this work focuses on regime shifts and cross-scale interactions but provides a deeper understanding of the social dimension, such as culture, institutions, networks, and agency, of such shifts. The analysis of systemic shifts between different social, ecological, and socialecological regimes also points to the possible barriers to sustainability transformations (Gunderson et al. 1995, Olsson et al. 2007, 2010, Sendzimir et al. 2008). These barriers often have a social origin, e.g., "culture and cognition and expressed through economic and social policies, land-use legislation, resource management practices, and other institutions and social practices" (O'Brien 2012:5).

Recently, other research initiatives, some linked to the NeWater project, to understand large-scale water management transitions have combined insights from resilience thinking and transition management. These include the role of policy entrepreneurs (Huitema and Meijerink 2010), flood management (Frantzeskaki et al. 2010), experimentation (Farrelly and Brown 2011), and pilot projects (Vreugdenhil et al. 2010), as well as how strategic planning should be made operational to enable transition to sustainable urban water management (Ferguson et al. 2013b).

Although some studies compare the different schools (van der Brugge and van Raak 2007, Foxon et al. 2009, Frantzeskaki et al. 2010, Ferguson et al. 2013a), others have combined insights from transition management and resilience research to focus on sustainability transformations in certain fields such as food production (Park et al. 2012), urbanization (Elmqvist et al. 2013), or global energy systems (Cherp et al. 2011). Roggema (2008) combines these two fields to develop the concept of "swarm planning," a new spatial design and planning paradigm that can deal with uncertainty and change. In the policy community, there are also attempts to draw on and combine these insights to initiate transformations. For example, in New South Wales, Australia, practitioners use resilience thinking and transition management to leverage change toward new landscape planning and management (Griffith et al. 2010).

Westley and colleagues (2011), explore the role of social innovation for sustainability transformations in the Anthropocene. Their analysis is an implicit attempt to integrate insights from transition management, social innovation, and resilience research. Compared to previous work on transitions and transformations in resilience research (e.g., Olsson et al. 2004b, 2006, Biggs et al. 2010), Westley et al. (2011) elaborate more explicitly the role of institutional entrepreneurs and the institutional context for the cross-scale dynamics of innovation.

\section{CONCLUSIONS}

History has provided us numerous examples of major sociotechnological advances. The problem, therefore, is not a lack of individual and societal innovative and transformative capacity, but rather how this capacity can be used to solve social and environmental problems and create the conditions for human welfare both today and in the future. Integrating transition management and resilience theory can contribute to the understanding of how to form niches for experimenting with initiatives that increase human well-being in the face of uncertainty and change, while simultaneously supporting ecosystem capacity. Another question that these fields could explore together is how ideas and innovations originating in these niches can have impact at a scale that matches global challenges and contributes to sustainability transformations.

The attempts mentioned previously, which combine different research fields, offer hope for continued theoretical integration and collaboration. However, they also illustrate the long way that lies ahead in trying to achieve an integrated understanding. We propose three interlinked research areas that need an integrated approach and on which such research collaboration could focus: (1) patterns of transformation; (2) innovation and social, technological, and ecological interactions at multiple levels in relation to sustainability; and (3) agency and its role in sustainability transformations.

\section{Patterns}

Transformative change is emergent and context specific, which makes each transformation unique. Nevertheless, transition management and resilience scholars have identified some general patterns of how sustainability transformations evolve over time. This includes incremental as well as abrupt change, thresholds and tipping points, cross-scale dynamics, and multiple phases. Still, a coherent theory for the emergence of new configurations of interconnected social-ecological systems with different sets of feedbacks is still lacking. This would address lock-in mechanisms and barriers to change, such as cognitive maps, power, and politics. It would also address opportunities and leverage points and mechanisms for breaking lock-ins and spur sustainability transformations. In this context, feedback mapping (see, e.g., Sendzimir et al. 2011) is a useful tool for exploring different socialecological regimes and pathways. However, many current attempts to map social-ecological systems tend to be biased toward the biophysical aspects (Nyström et al. 2012) and need to incorporate social factors. The feedback mapping of obesity in the United Kingdom is a case in point illustrating the type of social factors that need to be mapped, including social and individual psychology (Butland et al. 2007).

A new theory could also help develop analytical frameworks for studying the interactions between crisis and opportunity, e.g., how the recent food, finance, and climate crises open up opportunities for and trigger large-scale, systemic shifts toward global sustainability (see, e.g., Loorbach and Lijnis Huffenreuter [2013] for recent work on the global economic crisis). This would help broaden current analysis of sustainability transformations that focus solely on crisis to address crisis as part of the larger opportunity context, e.g., crises in interaction with other factors such as political elections and economic incentives for change, 
which needs to be navigated for achieving large-scale change (Westley et al. 2011).

\section{Innovation}

Technological innovations such as information and communication technology, nano- and biotechnology, synthetic biology, new energy systems, and proposed geoengineering techniques are likely to induce important large-scale transformations in society. Similarly, social innovations such as new governance modes, business models, microcredits, and crowd sourcing can also contribute to these large-scale changes. Hence, such innovations can be important tools for staying within the just and safe space for humanity (sensu Raworth 2013), but they require critical review (Rockström et al. 2009, Biggs et al. 2010, Westley et al. 2011, Olsson and Galaz 2012, Galaz 2014).

It should be noted that much of this innovation has occurred without reference to ecological integrity. If emerging institutions at multiple levels fail to incorporate the capacity of the biosphere to provide ecosystem services in framing the development and application of these innovations, there is a tangible risk that they may reinforce unsustainable development pathways (Olsson and Galaz 2012). This calls for a more explicit focus by sustainability transformation scholars on emerging technologies and social innovations, and the exploration of the features of institutional settings that allow for novelty, fail-safe experimentation, and continuous learning, but also weeding out innovations that carry considerable ecological and social risk (Evans et al. 2010, Leach et al. 2012). This is to ensure that innovations continue to have positive social and ecological effects when they are scaled up. In essence, this implies more deep engagement by transformation scholars in understanding the dynamics of technological change (e.g., Arthur 2009) and its linkages to ecosystems and the Earth system (Galaz 2012, 2014).

One of the key concerns with technological and social innovations that are promoted to deal with the challenges of the Anthropocene is that they are often top-down approaches designed as prepackaged solutions in the form of technology, user practices, services, and business models imposed on people and communities (Smith et al. 2014). The problem is not that knowledge is coming from the outside, but rather that people are obliged to adapt to a standard "solution" rather than the solution being adapted to specific ecological, social, and cultural conditions. A key research focus is therefore inclusive innovation and the role of interactive innovation spaces and change labs within which farmers, researchers, businesses, policy makers, and others can coproduce solutions (Leach et al. 2012, Seyfang and Haxeltine 2012).

Linked to this is also the need for studies of how global governance and new international regimes, institutions, and agreements can open up space for coproduction of innovation and the emergence of new management and governance approaches for sustainability at other levels (Marinova 2009, Galaz et al. 2012a). To answer questions about transformations toward global sustainability, such studies need to develop analytical tools and frameworks that can address social, technological, and ecological aspects.

\section{Agency}

Research has shown the important role of policy or institutional entrepreneurship and transformational leadership in sustainability transformations, including coordinating collaboration, staking out new pathways, identifying leverage points, developing strategies for overcoming barriers, and linking strategies to the specific opportunity context for gaining momentum for change. However, there is a lack of a coherent theory of the role of agents in these transformations and the strategic actions they employ (Westley et al. 2013). This involves moving focus away from the role of individual leaders to interacting key individuals and how strategies for change play out in multilevel, multiphase contexts. Such a theory could help formulate questions of how strategies are linked to transformative capacity and their role in gaining momentum for change and overcoming interacting barriers to transformations, such as vested interests, power, political conflict, and people's cognitive maps (Olsson et al. 2004b). It could also help explore how different capacities are needed for different phases of a transformation. For example, the capacity for promoting experimentation and fostering a diversity of available ideas, as part of "preparing for transformation," could be important for being ready when an opportunity presents itself. A capacity that might be very different from the capacities needed for "navigating the transition" or "building the resilience of the new direction."

Focusing on agency is particularly important for understanding the disruptiveness of innovation and how the scaling-up of innovations, technological and social, can have a large-scale impact (Westley et al. 2013). This involves the role of agents as "intermediaries" and "brokers" and addressing the scalespanning activities of interacting individuals and networks. Longitudinal network analysis (see, e.g., McCulloh and Carley 2011) is a promising analytical tool for understanding the relationship between change agents and topological phase network transitions in relation to multiple phases and scales. Such analytical tools can help to address questions of how individuals, small groups of self-organized actors, and informal networks, or shadow networks, can start unlocking self-reinforcing feedbacks that sustain unsustainable trajectories. However, it is important that such analyses consider and include social-ecologicaltechnological interactions in the emergence of new pathways.

Responses to this article can be read online at: http://www.ecologyandsociety.org/issues/responses. $\mathrm{php} / 6799$

\section{Acknowledgments:}

This research has been supported by the Stockholm Resilience Centre through grants from the Foundation for Strategic Environmental Research (Mistra). We also thank the two anonymous reviewers for constructive comments on this work.

\section{LITERATURE CITED}

Adger, W. N., K. Brown, and E. L. Tompkins. 2005. The political economy of cross-scale networks in resource co-management. Ecology and Society 10(2): 9. [online] URL: http://www. ecologyandsociety.org/vol10/iss2/art9/

Anderies, J. M., C. Folke, B. Walker, and E. Ostrom. 2013. Aligning key concepts for global change policy: robustness, 
resilience, and sustainability. Ecology and Society 18(2): 8. http:// dx.doi.org/10.5751/ES-05178-180208

Armitage, D., F. Berkes, and N. Doubleday, editors. 2007. Adaptive comanagement: collaboration, learning and multilevel governance. University of British Columbia Press, Vancouver, British Columbia, Canada.

Arthur, W. B. 2009. The nature of technology: what it is and how it evolves. Free, New York, New York, USA.

Avelino, F. 2009. Empowerment and the challenge of applying transition management to ongoing projects. Policy Sciences 42:369-390. http://dx.doi.org/10.1007/s11077-009-9102-6

Avelino, F., and J. Rotmans. 2009. Power in transition: an interdisciplinary framework to study power in relation to structural change. European Journal of Social Theory 12:543-569. http://dx.doi.org/10.1177/1368431009349830

Avelino, F., and J. Rotmans. 2011. A dynamic conceptualization of power for sustainability research. Journal of Cleaner Production 19:796-804. http://dx.doi.org/10.1016/j.jclepro.2010.11.012

Berkes, F., J. Colding, and C. Folke, editors. 2003. Navigating social-ecological systems: building resilience for complexity and change. Cambridge University Press, Cambridge, UK. http://dx. doi.org/10.1017/CBO9780511541957

Berkes, F., and C. Folke, editors. 1998. Linking social and ecological systems: management practices and social mechanisms for building resilience. Cambridge University Press, Cambridge, UK.

Biggs, R., F. R. Westley, and S. R. Carpenter. 2010. Navigating the back loop: fostering social innovation and transformation in ecosystem management. Ecology and Society 15(2): 9. [online] URL: http://www.ecologyandsociety.org/vol15/iss2/art9/

Boonstra, W. J., and F. W. de Boer. 2014. The historical dynamics of social-ecological traps. AMBIO 43:260-274. http://dx.doi. org/10.1007/s13280-013-0419-1

Bormann, B. T., and A. R. Kiester. 2004. Options forestry: acting on uncertainty. Journal of Forestry 102:22-27.

Borras, S. M., Jr., and J. Franco. 2010. Towards a broader view of the politics of global land grabbing: rethinking land issues, reframing resistance. Initiatives in Critical Agrarian Studies Working Paper Series No. 1. International Institute of Social Studies, The Hague, The Netherlands.

Brown, K. 2014. Global environmental change I: a social turn for resilience? Progress in Human Geography 38:107-117. http://dx. doi.org/10.1177/0309132513498837

Brown, K., and E. Westaway. 2011. Agency, capacity, and resilience to environmental change: lessons from human development, well-being, and disasters. Annual Review of Environment and Resources 36:321-342. http://dx.doi.org/10.1146/ annurev-environ-052610-092905

Butland B., S. Jebb, P. Kopelman, K. McPherson, S. Thomas, J. Mardell, and V. Parry. 2007. FORESIGHT: tackling obesities: future choices-project report. Second edition. Government Office for Science, London, UK. [online] URL: http://webarchive. nationalarchives.gov.uk/20121212135622/http://www.bis.gov.uk/assets/ bispartners/foresight/docs/obesity/17.pdf
Cash, D. W., W. Adger, F. Berkes, P. Garden, L. Lebel, P. Olsson, L. Pritchard, and O. Young. 2006. Scale and cross-scale dynamics: governance and information in a multilevel world. Ecology and Society 11(2): 8. [online] URL: http://www.ecologyandsociety. org/vol11/iss2/art8/

Chapin, F. S., III, S. R. Carpenter, G. P. Kofinas, C. Folke, N. Abel, W. C. Clark, P. Olsson, D. M. Stafford Smith, B. Walker, O. R. Young, F. Berkes, R. Biggs, J. M. Grove, R. L. Naylor, E. Pinkerton, W. Steffen, and F. J. Swanson. 2010. Ecosystem stewardship: sustainability strategies for a rapidly changing planet. Trends in Ecology and Evolution 25:241-249. http://dx.doi. org/10.1016/j.tree.2009.10.008

Cherp, A., J. Jewell, and A. Goldthau. 2011. Governing global energy: systems, transitions, complexity. Global Policy 2:75-88. http://dx.doi.org/10.1111/j.1758-5899.2010.00059.x

Cinner, J. E., T. M. Daw, T. R. McClanahan, N. Muthiga, C. Abunge, S. Hamed, B. Mwaka, A. Rabearisoa, A. Wamukota, E. Fisher, and N. Jiddawi. 2012. Transitions toward co-management: the process of marine resource management devolution in three east African countries. Global Environmental Change 22:651-658. http://dx.doi.org/10.1016/j.gloenvcha.2012.03.002

Clark, W. C. 2001. A transition toward sustainability. Ecology Law Quarterly 27:1021-1076.

Cowling R. M., B. Egoh, A. T. Knight, P. J. O'Farrel, B. Reyers, M. Rouget, D. J. Roux, A. Welz, and A. Wilhelm-Rechman. 2008. An operational model for mainstreaming ecosystem services for implementation. Proceedings of the National Academy of Sciences of the United States of America 105:9483-9488. http://dx.doi. org/10.1073/pnas.0706559105

Crona, B., and Ö. Bodin. 2010. Power asymmetries in small-scale fisheries: a barrier to governance transformability? Ecology and Society 15(4): 32. [online] URL: http://www.ecologyandsociety. org/vol15/iss4/art32/

Cumming, G. S., P. Olsson, F. S. Chapin III, and C. S. Holling. 2013. Resilience, experimentation, and scale mismatches in socialecological landscapes. Landscape Ecology 28:1139-1150. http:// dx.doi.org/10.1007/s10980-012-9725-4

Elmqvist, T., M. Fragkias, J. Goodness, B. Güneralp, P. J. Marcotullio, R. I. McDonald, S. Parnell, M. Schewenius, M. Sendstad, K. C. Seto, C. Wilkinson, M. Alberti, C. Folke, N. Frantzeskaki, D. Haase, M. Katti, H. Nagendra, J. Niemelä, S. T. A. Pickett, C. L. Redman, and K. Tidball. 2013. Stewardship of the biosphere in the urban era. Pages 719-746 in T. Elmqvist, M. Fragkias, J. Goodness, B. Güneralp, P. J. Marcotullio, R. I. McDonald, S. Parnell, M. Schewenius, M. Sendstad, K. C. Seto, and C. Wilkinson, editors. Urbanization, biodiversity and ecosystem services: challenges and opportunities. Springer, Dordrecht, The Netherlands. http://dx.doi.org/10.1007/978-94-$\underline{007-7088-133}$

Enfors, E. 2013. Social-ecological traps and transformations in dryland agro-ecosystems: using water system innovations to change the trajectory of development. Global Environmental Change 23:51-60. http://dx.doi.org/10.1016/j.gloenvcha.2012.10.007

Ernstson, H., S. Sörlin, and T. Elmqvist. 2008. Social movements and ecosystem services-the role of social network structure in protecting and managing urban green areas in Stockholm. 
Ecology and Society 13(2): 39. [online] URL: http://www. ecologyandsociety.org/vol13/iss2/art39/

Evans, A., B. Jones, and D. Steven 2010. Confronting the long crisis of globalization: risk, resilience and international order. Brookings/ Center on International Cooperation, Washington, D.C., USA. [online] URL: http://www.brookings.edu/ /media/research/files/ reports/2010/1/26\%20globalization $\% 20$ jones/01_globalization_evans jones steven.pdf

Farrelly, M., and R. Brown. 2011. Rethinking urban water management: experimentation as a way forward? Global Environmental Change 21:721-732. http://dx.doi.org/10.1016/j. gloenvcha.2011.01.007

Ferguson, A. 1995 [1767]. An essay on the history of civil society. Transaction, New Brunswick, New Jersey, USA.

Ferguson, B. C., R. R. Brown, and A. Deletic. 2013a. A diagnostic procedure for transformative change based on transitions, resilience, and institutional thinking. Ecology and Society 18(4): 57. http://dx.doi.org/10.5751/ES-05901-180457

Ferguson, B. C., N. Frantzeskaki, and R. R. Brown. 2013b. A strategic program for transitioning to a Water Sensitive City. Landscape and Urban Planning 117:32-45. http://dx.doi. org/10.1016/j.landurbplan.2013.04.016

Flyvbjerg, B. 2001. Making social science matter: why social inquiry fails and how it can succeed again. Cambridge University Press, Cambridge, UK. http://dx.doi.org/10.1017/CBO9780511810503

Folke, C., S. R. Carpenter, B. Walker, M. Scheffer, T. Chapin, and J. Rockström. 2010. Resilience thinking: integrating resilience, adaptability and transformability. Ecology and Society 15(4): 20. [online] URL: http://www.ecologyandsociety.org/vol15/iss4/ $\underline{\operatorname{art} 20 /}$

Folke, C., Å. Jansson, J. Rockström, P. Olsson, S. R. Carpenter, F. S. Chapin III, A.-S. Crepín, G. Daily, K. Danell, J. Ebbesson, T. Elmqvist, V. Galaz, F. Moberg, M. Nilsson, H. Österblom, E. Ostrom, A. Persson, G. Peterson, S. Polasky, W. Steffen, B. Walker, and F. Westley. 2011. Reconnecting to the biosphere. AMBIO 40:719-738. http://dx.doi.org/10.1007/s13280-011-0184-y

Foxon, T. J., M. S. Reed, and L. C. Stringer. 2009. Governing long-term social-ecological change: what can the adaptive management and transition management approaches learn from each other? Environmental Policy and Governance 19:3-20. http:// dx.doi.org/10.1002/eet.496

Frantzeskaki, N., J. Slinger, H. Vreugdenhil, and E. van Daalen. 2010. Social-ecological systems governance: from paradigm to management approach. Nature and Culture 5:84-98. http://dx.doi. org/10.3167/nc. 2010.050106

Galaz, V. 2005. Social-ecological resilience and social conflict: institutions and strategic adaptation in Swedish water management. AMBIO 34:567-572. http://dx.doi.

org/10.1579/0044-7447-34.7.567

Galaz, V. 2012. Geo-engineering, governance, and socialecological systems: critical issues and joint research needs. Ecology and Society 17(1): 24. http://dx.doi.org/10.5751/ ES-04677-170124
Galaz, V. 2014. Global environmental governance, technology and politics: the Anthropocene Gap. Edward Elgar, Cheltenham, UK. http://dx.doi.org/10.4337/9781781955550

Galaz, V., F. Biermann, B. Crona, D. Loorbach, C. Folke, P. Olsson, M. Nilsson, J. Allouche, A. Persson, and G. Reischl. 2012a. 'Planetary boundaries'-exploring the challenges for global environmental governance. Current Opinion in Environmental Sustainability 4:80-87. http://dx.doi.org/10.1016/j. cosust.2012.01.006

Galaz, V., B. Crona, H. Österblom, P. Olsson, and C. Folke. 2012 b. Polycentric systems and interacting planetary boundariesemerging governance of climate change-ocean acidificationmarine biodiversity. Ecological Economics 81:21-32. http://dx. doi.org/10.1016/j.ecolecon.2011.11.012

Geels, F. W., and J. Schot. 2007. Typology of sociotechnical transition pathways. Research Policy 36:399-417. http://dx.doi. org/10.1016/j.respol.2007.01.003

Gelcich, S., T. P. Hughes, P. Olsson, C. Folke, O. Defeo, M. Fernández, S. Foale, L. H. Gunderson, C. Rodríguez-Sickert, M. Scheffer, R. S. Steneck, and J. C. Castilla. 2010. Navigating transformations in governance of Chilean marine coastal resources. Proceedings of the National Academy of Sciences of the United States of America 107:16794-16799. http://dx.doi. org/10.1073/pnas.1012021107

Gell-Mann, M. 2010. Transformations of the twenty-first century: transitions to greater sustainability. Pages 1-8 in J. Schellnhuber, M. Molina, N. Stern, V. Huber, and S. Kadner, editors. Global sustainability: a Nobel cause. Cambridge University Press, Cambridge, Massachusetts, USA.

Grau, H. R., and M. Aide. 2008. Globalization and land-use transitions in Latin America. Ecology and Society 13(2): 16. [online] URL: http://www.ecologyandsociety.org/vol13/iss2/ art16/

Griffith, R., M. Mitchell, G. Walkerden, V. Brown, and B. Walker. 2010. Building a framework for transformative action in the Wakool Shire. Transformation for resilient landscapes and communities project. Working Paper 1. Report No. 61, Institute for Land, Water and Society (ILWS). ILWS, Charles Sturt University, Albury, New South Wales, Australia.

Grin, J., J. Rotmans, and J. Schot. 2010. Transitions to sustainable development: new directions in the study of long-term transformative change. Routledge, New York, New York, USA.

Gunderson, L. H., and C. S. Holling, editors. 2002. Panarchy: understanding transformations in human and natural systems. Island, Washington, D.C., USA.

Gunderson, L. H., C. S. Holling, and S. S. Light, editors. 1995. Barriers and bridges to renewal of ecosystems and institutions. Columbia University Press, New York, New York, USA.

Hegmon, M., M. A. Peeples, A. P. Kinzig, S. Kulow, C. M. Meegan, and M. C. Nelson. 2008. Social transformation and its human costs in the prehispanic U.S. Southwest. American Anthropologist 110:313-324. http://dx.doi.org/10.1111/ j.1548-1433.2008.00041.x 
Holling, C. S., editor. 1978. Adaptive environmental assessment and management. John Wiley, New York, New York, USA.

Holling, C. S., L. H. Gunderson, and G. D. Peterson. 2002. Sustainability and panarchies. Pages 63-102 in L. H. Gunderson and C. S. Holling, editors. Panarchy: understanding transformations in human and natural systems. Island, Washington, D.C., USA.

Hornborg, A. 2009. Zero-sum world: challenges in conceptualizing environmental load displacement and ecologically unequal exchange in the world-system. International Journal of Comparative Sociology 50:237-262. http://dx.doi. org/10.1177/0020715209105141

Huitema, D., and S. Meijerink. 2010. Realizing water transitions: the role of policy entrepreneurs in water policy change. Ecology and Society 15(2): 26. [online] URL: http://www.ecologyandsociety. org/vol15/iss2/art26/

Jerneck, A., and L. Olsson. 2008. Adaptation and the poor: development, resilience and transition. Climate Policy 8:170-182. http://dx.doi.org/10.3763/cpol.2007.0434

Kates, R. W., W. C. Clark, R. Corell, J. M. Hall, C. C. Jaeger, I. Lowe, J. J. McCarthy, H. J. Schellnhuber, B. Bolin, N. M. Dickson, S. Faucheux, G. C. Gallopin, A. Grübler, B. Huntley, J. Jäger, N. S. Jodha, R. E. Kasperson, A. Mabogunje, P. Matson, H. Mooney, B. Moore III, T. O'Riordan, and U. Svedin. 2001. Sustainability science. Science 292:641-642. http://dx.doi.org/10.1126/science.1059386

Kok, K., and T. A. Veldkamp. 2011. Scale and governance: conceptual considerations and practical implications. Ecology and Society 16(2): 23. [online] URL: http://www.ecologyandsociety. org/vol16/iss2/art23/

Leach, M., J. Rockström, P. Raskin, I. Scoones, A. C. Stirling, A. Smith, J. Thompson, E. Millstone, A. Ely, E. Arond, C. Folke, and P. Olsson. 2012. Transforming innovation for sustainability. Ecology and Society 17(2): 11. http://dx.doi.org/10.5751/ ES-04933-170211

Leach, M., I. Scoones, and A. Stirling. 2007. Pathways to sustainability: an overview of the STEPS Centre approach. STEPS Centre, Brighton, UK.

Lebel, L., J. M. Anderies, B. Campbell, C. Folke, S. HatfieldDodds, T. P. Hughes, and J. Wilson. 2006. Governance and the capacity to manage resilience in regional social-ecological systems. Ecology and Society 11(1): 19. [online] URL: http://www. ecologyandsociety.org/vol11/iss1/art19/

Lélé, S., and R. B. Norgaard. 2005. Practicing interdisciplinarity. BioScience 55:967-975. http://dx.doi.org/10.1641/0006-3568 (2005)055[0967:PI]2.0.CO;2

Lindblom, C. E. 1959. The science of "muddling through." Public Administration Review 19:79-88. http://dx.doi.org/10.2307/973677

Lindblom, C. E. 1979. Still muddling, not yet through. Public Administration Review 39:517-526. http://dx.doi.org/10.2307/976178

Loorbach, D. 2010. Transition management for sustainable development: a prescriptive, complexity-based governance framework. Governance 23:161-183. http://dx.doi.org/10.1111/ j.1468-0491.2009.01471.x
Loorbach, D. A., and R. Lijnis Huffenreuter. 2013. Exploring the economic crisis from a transition management perspective. Environmental Innovation and Societal Transitions 6:35-46. http:// dx.doi.org/10.1016/j.eist.2013.01.003

Loorbach, D., and J. Rotmans. 2010. The practice of transition management: examples and lessons from four distinct cases. Futures 42:237-246. http://dx.doi.org/10.1016/j.futures.2009.11.009

Lukes, S. 1974. Power: a radical view. Palgrave Macmillan, London, UK.

Marinova, D. 2009. Global green system of innovation: technological wave or policy? Pages 1168-1174 in R. S. Anderssen, R. D. Braddock, and L. T. H. Newham, editors. MODSIM 2009 International Congress on Modelling and Simulation (Cairns, Australia, 13-17 July 2009). Modelling and Simulation Society of Australia and New Zealand, Cairns, Queensland, Australia. [online] URL: http://espace.library.curtin.edu.au/cgi-bin/espace. pdf?file $=/ 2011 / 10 / 19 /$ file $1 / 160832$

Marschke, M. J., and F. Berkes. 2006. Exploring strategies that build livelihood resilience: a case from Cambodia. Ecology and Society 11(1): 42. [online] URL: http://www.ecologyandsociety. org/vol11/iss1/art42/

Marshall, N. A., S. E. Park, W. N. Adger, K. Brown, and S. M. Howden. 2012. Transformational capacity and the influence of place and identity. Environmental Research Letters 7:034022. http://dx.doi.org/10.1088/1748-9326/7/3/034022

Marshall, G. R., and D. M. Stafford Smith. 2010. Natural resources governance for the drylands of the Murray-Darling Basin. Rangeland Journal 32:267-282. http://dx.doi.org/10.1071/ $\underline{\mathrm{RJ} 10020}$

McCulloh, I., and K. M. Carley. 2011. Detecting change in longitudinal social networks. Journal of Social Structure 12 (3):1-37.

Miller, T. R., T. D. Baird, C. M. Littlefield, G. Kofinas, F. Chapin III, and C. L. Redman. 2008. Epistemological pluralism: reorganizing interdisciplinary research. Ecology and Society 13 (2): 46. [online] URL: http://www.ecologyandsociety.org/vol13/ iss $2 / \operatorname{art} 46 /$

Moore, M.-L., and O. Tjornbo. 2012. From coastal timber supply area to Great Bear Rainforest: exploring power in a socialecological governance innovation. Ecology and Society 17(4): 26. http://dx.doi.org/10.5751/ES-05194-170426

Morriss, P. 2002. Power: a philosophical analysis. Second edition. Manchester University Press, Manchester, UK.

Motion, J. 2005. Participative public relations: power to the people or legitimacy for government discourse? Public Relations Review 31:505-512. http://dx.doi.org/10.1016/j.pubrev.2005.08.009

Nadasdy, P. 2007. Adaptive co-management and the gospel of resilience. Pages 208-226 in D. Armitage, F. Berkes, and N. Doubleday, editors. Adaptive co-management: collaboration, learning, and multi-level governance. University of British Columbia Press, Vancouver, British Columbia, Canada.

Nyström, M., A. V. Norström, T. Blenckner, M. de la TorreCastro, J. S. Eklöf, C. Folke, H. Österblom, R. S. Steneck, M. 
Thyresson, and M. Troell. 2012. Confronting feedbacks of degraded marine ecosystems. Ecosystems 15:695-710. http://dx. doi.org/10.1007/s10021-012-9530-6

O'Brien, K. 2012. Global environmental change II: from adaptation to deliberate transformation. Progress in Human Geography 36:667-676. http://dx.doi.org/10.1177/0309132511425767

Olsson, P., Ö. Bodin, and C. Folke. 2010. Building transformative capacity for ecosystem stewardship in social-ecological systems. Pages 263-285 in D. Armitage and R. Plummer, editors. Adaptive capacity and environmental governance. Springer-Verlag, Berlin, Germany. http://dx.doi.org/10.1007/978-3-642-12194-4_13

Olsson, P., C. Folke, and F. Berkes. 2004a. Adaptive comanagement for building social-ecological resilience. Environmental Management 34:75-90. http://dx.doi.org/10.1007/ $\underline{\text { s00267-003-0101-7 }}$

Olsson, P., C. Folke, V. Galaz, T. Hahn, and L. Schultz. 2007. Enhancing the fit through adaptive co-management: creating and maintaining bridging functions for matching scales in the Kristianstads Vattenrike Biosphere Reserve Sweden. Ecology and Society 12(1): 28. [online] URL: http://www.ecologyandsociety. org/vol12/iss1/art28/

Olsson, P., C. Folke, and T. Hahn. 2004b. Social-ecological transformation for ecosystem management: the development of adaptive comanagement of a wetland landscape in southern Sweden. Ecology and Society 9(4): 2. [online] URL: http://www. ecologyandsociety.org/vo19/iss4/art2/

Olsson, P., C. Folke, and T. P. Hughes. 2008. Navigating the transition to ecosystem-based management of the Great Barrier Reef, Australia. Proceedings of the National Academy of Sciences of the United States of America 105:9489-9494. http://dx.doi. org/10.1073/pnas.0706905105

Olsson, P., and V. Galaz. 2012. Social-ecological innovation and transformation. Pages 223-243 in A. Nicholls and A. Murdoch, editors. Social innovation: blurring boundaries to reconfigure markets. Palgrave MacMillan, Basingstoke, UK. http://dx.doi. org/10.1057/9780230367098.0018

Olsson, P., L. H. Gunderson, S. R. Carpenter, P. Ryan, L. Lebel, C. Folke, and C. S. Holling. 2006. Shooting the rapids: navigating transitions to adaptive governance of social-ecological systems. Ecology and Society 11(1): 18. [online] URL: http://www. ecologyandsociety.org/vol11/iss1/art18/

Österblom, H., and C. Folke. 2013. Emergence of global adaptive governance for stewardship of regional marine resources. Ecology and Society 18(2): 4. http://dx.doi.org/10.5751/ES-05373-180204

Österblom, H., and U. R. Sumaila. 2011. Toothfish crises, actor diversity and the emergence of compliance mechanisms in the Southern Ocean. Global Environmental Change 21:972-982. http://dx.doi.org/10.1016/j.gloenvcha.2011.04.013

Pahl-Wostl, C., T. Downing, P. Kabat, P. Magnuszewski, J. Meigh, M. Schlueter, J. Sendzimir, and S. Werners. 2005. Transition to adaptive water management: the NeWater Project. NeWater Working Paper No. 1. Institute of Environmental Systems Research, University of Osnabrück, Osnabrück, Germany. [online] URL: http://www.newater.uos.de/intern/sendfile.php? $\underline{\mathrm{id}=48}$
Pahl-Wostl, C., J. Sendzimir, P. Jeffrey, J. Aerts, G. Berkamp, and K. Cross. 2007. Managing change toward adaptive water management through social learning. Ecology and Society 12(2): 30. [online] URL: http://www.ecologyandsociety.org/vol12/iss $2 /$ $\underline{\operatorname{art} 30 /}$

Park, S. E., N. A. Marshall, E. Jakku, A. M. Dowd, S. M. Howden, E. Mendham, and A. Fleming. 2012. Informing adaptation responses to climate change through theories of transformation. Global Environmental Change 22:115-126. http://dx.doi. org/10.1016/j.gloenvcha.2011.10.003

Pelling, M., and D. Manuel-Navarrete. 2011. From resilience to transformation: the adaptive cycle in two Mexican urban centers. Ecology and Society 16(2): 11. [online] URL: http://www. ecologyandsociety.org/vol16/iss2/art11/

Peterson, G. 2000. Political ecology and ecological resilience: an integration of human and ecological dynamics. Ecological Economics 35:323-336. http://dx.doi.org/10.1016/S0921-8009(00) $\underline{00217-2}$

Peterson, G. D., T. D. Beard Jr., B. E. Beisner, E. M. Bennett, S. R. Carpenter, G. S. Cumming, C. L. Dent, and T. D. Havlicek. 2003. Assessing future ecosystem services: a case study of the Northern Highlands Lake District, Wisconsin. Conservation Ecology 7(3): 1. [online] URL: http://www.consecol.org/vol7/iss3/ art1/

Popper, K. R. 1960 [1957]. The poverty of historicism. Routledge and Kegan Paul, London, UK.

Popper, K. R. 1962 [1945]. The open society and its enemies. Volume 2, the high tide of prophecy: Hegel, Marx and the aftermath. Harper Torch Books, New York, New York, USA.

Portes, A. 2000. The hidden abode: sociology as analysis of the unexpected. American Sociological Review 65:1-18. http://dx.doi. org/10.2307/2657287

Raskin, P., T. Banuri, G. Gallopin, P. Gutman, A. Hammond, R. Kates, and R. Swart. 2002. Great transition: the promise and lure of the times ahead. A report of the Global Scenario Group. Stockholm Environmental Institute, Tellus Institute, and Great Transition Initiative, Boston, Massachusetts, USA.

Raworth, K. 2013. Defining a safe and just space for humanity. Pages 28-38 in The Worldwatch Institute, editor. State of the world 2013: is sustainability still possible? Island/Center for Resource Economics and the Worldwatch Institute, Washington, D.C., USA. http://dx.doi.org/10.5822/978-1-61091-458-1 3

Reij, C. P., and E. M. A. Smaling. 2008. Analyzing successes in agriculture and land management in Sub-Saharan Africa: is macro-level gloom obscuring positive micro-level change? Land Use Policy 25:410-420. http://dx.doi.org/10.1016/j.landusepol.2007.10.001

Rockström, J., W. Steffen, K. Noone, Å. Persson, F. S. Chapin III, E. F. Lambin, T. M. Lenton, M. Scheffer, C. Folke, H. J. Schellnhuber, B. Nykvist, C. A. de Wit, T. Hughes, S. van der Leeuw, H. Rodhe, S. Sörlin, P. K. Snyder, R. Costanza, U. Svedin, M. Falkenmark, L. Karlberg, R. W. Corell, V. J. Fabry, J. Hansen, B. Walker, D. Liverman, K. Richardson, P. Crutzen, and J. A. Foley. 2009. A safe operating space for humanity. Nature 461:472-475. http://dx.doi.org/10.1038/461472a 
Roggema, R. E. 2008. Swarm planning: a new design paradigm dealing with long-term problems associated with turbulence. Pages 103-130 in J. W. W. Selsky, R. Ramirez, and K. van der Heijden, editors. Business planning for turbulent times: new methods for applying scenarios. Earthscan, London, UK.

Rosen, F., and P. Olsson. 2013. Institutional entrepreneurs, global networks, and the emergence of international institutions for ecosystem-based management: the Coral Triangle Initiative. Marine Policy 38:195-204. http://dx.doi.org/10.1016/j. marpol.2012.05.036,

Rotmans, J., R. Kemp, and M. van Asselt. 2001. More evolution than revolution: transition management in public policy. Foresight 3:15-31. http://dx.doi.org/10.1108/14636680110803003

Rudd, M. A. 2004. An institutional framework for designing and monitoring ecosystem-based fisheries management policy experiments. Ecological Economics 48:109-124. http://dx.doi. org/10.1016/j.ecolecon.2003.10.002

Schellnhuber, H. J., D. Messner, C. Leggewie, R. Leinfelder, N. Nakicenovic, S. Rahmstorf, S. Schlacke, J. Schmid, and R. Schubert. 2011. World in transition: a social contract for sustainability. German Advisory Council on Global Change, Berlin, Germany.

Schlüter, M., and E. Herrfahrdt-Pähle. 2011. Exploring resilience and transformability of a river basin in the face of socioeconomic and ecological crisis: an example from the Amudarya river basin, Central Asia. Ecology and Society 16(1): 32. [online] URL: http:// www.ecologyandsociety.org/vol16/iss1/art32/

Scott, J. C. 1998. Seeing like a state: how certain schemes to improve the human condition have failed. Yale University Press, New Haven, Connecticut, USA.

Sendzimir, J., P. Magnuszewski, Z. Flachner, P. Balogh, G. Molnar, A. Sarvari, and Z. Nagy. 2008. Assessing the resilience of a river management regime: informal learning in a shadow network in the Tisza River Basin. Ecology and Society 13(1): 11. [online] URL: http://www.ecologyandsociety.org/vol13/iss1/ $\underline{\operatorname{art} 11 /}$

Sendzimir, J., C. P. Reij, and P. Magnuszewski. 2011. Rebuilding resilience in the Sahel: regreening in the Maradi and Zinder regions of Niger. Ecology and Society 16(3): 1. http://dx.doi. org/10.5751/ES-04198-160301

Seyfang, G., and A. Haxeltine. 2012. Growing grassroots innovations: exploring the role of community-based initiatives in governing sustainable energy transitions. Environment and Planning C: Government and Policy 30:381-400. http://dx.doi. org/10.1068/c10222

Smith, A., M. Fressoli, and H. Thomas. 2014. Grassroots innovation movements: challenges and contributions. Journal of Cleaner Production 63:114-124. http://dx.doi.org/10.1016/j. jclepro.2012.12.025

Smith, A., and A. Sterling. 2010. The politics of social-ecological resilience and sustainable socio-technical transitions. Ecology and Society 15(1): 11. [online] URL: http://www.ecologyandsociety. org/vol15/iss1/art11/
Sneddon, C. 2003. Reconfiguring scale and power: the KhongChi-Mun project in northeast Thailand. Environment and Planning A 35:2229-2250. http://dx.doi.org/10.1068/a35299

Steffen, W., Å. Persson, L. Deutsch, J. Zalasiewicz, M. Williams, K. Richardson, C. Crumley, P. Crutzen, C. Folke, L. Gordon, M. Molina, V. Ramanathan, J. Rockström, M. Scheffer, J. Schellnhuber, and U. Svedin. 2011. The Anthropocene: from global change to planetary stewardship. AMBIO 40:739-761. http://dx.doi.org/10.1007/s13280-011-0185-x

Steneck, R. S., T. P. Hughes, J. E. Cinner, W. N. Adger, S. N. Arnold, F. Berkes, S. A. Boudreau, K. Brown, C. Folke, L. Gunderson, P. Olsson, M. Scheffer, E. Stephenson, B. Walker, J. Wilson, and B. Worm. 2011. Creation of a gilded trap by the high economic value of the Maine lobster fishery. Conservation Biology 25:904-912. http://dx.doi.org/10.1111/j.1523-1739.2011.01717.x

Strang, V. 2009. Integrating the social and natural sciences in environmental research: a discussion paper. Environment, Development and Sustainability 11:1-18. http://dx.doi.org/10.1007/ s10668-007-9095-2

Tilly, C. 1999. Survey article: power-top down and bottom up. Journal of Political Philosophy 7:330-352. http://dx.doi. org/10.1111/1467-9760.00080

Van Apeldoorn, D. F., K. Kok, M. P. W. Sonneveld, and T. (A.) Veldkamp. 2011. Panarchy rules: rethinking resilience of agroecosystems, evidence from Dutch dairy-farming. Ecology and Society 16(1): 39. [online] URL: http://www.ecologyandsociety. org/vol16/iss $1 /$ art39/

van der Brugge, R., and R. van Raak. 2007. Facing the adaptive management challenge: insights from transition management. Ecology and Society 12(2): 33. [online] URL: http://www. ecologyandsociety.org/vol12/iss2/art33/

Vervoort, J. M., L. Rutting, K. Kok, F. L. P. Hermans, T. Veldkamp, A. K. Bregt, and R. van Lammeren. 2012. Exploring dimensions, scales, and cross-scale dynamics from the perspectives of change agents in social-ecological systems. Ecology and Society 17(4): 24. http://dx.doi.org/10.5751/ ES-05098-170424

Voß, J., and B. Bornemann. 2011. The politics of reflexive governance: challenges for designing adaptive management and transition management. Ecology and Society 16(2): 9. [online] URL: http://www.ecologyandsociety.org/vol16/iss2/art9/

Vreugdenhil, H., J. Slinger, W. Thissen, and P. Ker Rault. 2010. Pilot projects in water management. Ecology and Society 15(3): 13. [online] URL: http://www.ecologyandsociety.org/vol15/iss3/ $\underline{\operatorname{art} 13 /}$

Walker, B., S. Barrett, S. Polasky, V. Galaz, C. Folke, G. Engström, F. Ackerman, K. Arrow, S. Carpenter, K. Chopra, G. Daily, P. Ehrlich, T. Hughes, N. Kautsky, S. Levin, K.-G. Mäler, J. Shogren, J. Vincent, T. Xepapadeas, and A. de Zeeuw. 2009. Looming global-scale failures and missing institutions. Science 325:1345-1346. http://dx.doi.org/10.1126/science.1175325

Walker, B., C. S. Holling, S. R. Carpenter, and A. Kinzig. 2004. Resilience, adaptability and transformability in social-ecological 
systems. Ecology and Society 9(2): 5. [online] URL: http://www. ecologyandsociety.org/vol9/iss2/art5

Walker, B., and D. Salt. 2012. Resilience practice: building capacity to absorb disturbance and maintain function. Island/Center for Resource Economics, Washington, D.C., USA. http://dx.doi. org/10.5822/978-1-61091-231-0

Weinstein, M. P., R. E. Turner, and C. Ibáñez. 2013. The global sustainability transition: it is more than changing light bulbs. Sustainability: Science, Practice, \& Policy 9:4-15.

Westley, F., P. Olsson, C. Folke, T. Homer-Dixon, H. Vredenburg, D. Loorbach, J. Thompson, M. Nilsson, E. Lambin, J. Sendzimir, B. Banarjee, V. Galaz, and S. van der Leeuw. 2011. Tipping toward sustainability: emerging pathways of transformation. $A M B I O$ 40:762-780. http://dx.doi.org/10.1007/s13280-011-0186-9

Westley, F. R., O. Tjornbo, L. Schultz, P. Olsson, C. Folke, B. Crona, and Ö. Bodin. 2013. A theory of transformative agency in linked social-ecological systems. Ecology and Society 18(3): 27. http://dx.doi.org/10.5751/ES-05072-180327

Young, I. M. 2006. Responsibility and global justice: a social connection model. Social Philosophy and Policy 23:102-130. http://dx.doi.org/10.1017/S0265052506060043 